Arkhais, Vol. 06 No. 1 Januari-Juni 2015

\title{
METAFORA PADA RUBRIK OPINI HARIAN KOMPAS
}

\section{Ananda Nurahmi Berkah Nastiti}

\begin{abstract}
Abstrak. Penelitian ini bertujuan untuk mengetahui bagaimana penggunaan metafora dalam rubrik opini harian kompas ditinjau dari jenis berdasarkan pilihan citra dan jenis berdasarkan bentuk metafora yang muncul dalam rubrik opini Harian Kompas tersebut. Penelitian ini dilakukan pada bulan Maret sampai dengan Juni 2014. Objek penelitian ini adalah rubrik opini harian Kompas yang terbit dari bulan Januari sampai Maret 2014 dengan pengambilan secara reduksi. Metode yang digunakan dalam penelitian ini adalah metode kualitatif deskriptif dengan teknik analisis isi. Adapun fokus penelitian ini adalah penggunaan metafora ditinjau berdasarkan pilihan citra dan bentuk metafora yang muncul meliputi 8 (delapan) kriteria analisis, yaitu 1) metafora bercitra antropomorfik, 2) metafora bercitra hewan, 3) metafora bercitra abstrak ke konkret, 4) metafora bercitra sinestesia. Selain itu jenis metafora berdasarkan bentuk meliputi 1) nominatif subjektif, 2) nominatif objektif, 3) predikatif, 4) kalimat. Berdasarkan penelitian yang telah dilakukan, dapat disimpulkan bahwa dalam rubrik opini Harian Kompas ditemukan metafora sebanyak 121 metafora. Dari seluruh data metafora tersebut, terdapat 117 metafora yang mengandung citra antropomorfik, citra hewan, citra abstrak ke konkret, citra sinestesia dan menempati bentuk yang meliputi nominatif subjektif, nominatif objektif, predikatif, kalimat. Metafora bercitra antropomorfik sebanyak 39 buah $(33,4 \%)$, metafora bercitra hewan ditemukan sebanyak 25 buah $(21,4 \%)$, metafora bercitra abstrak ke konkret ditemukan sebanyak 37 buah (31,6\%), metafora bercitra sinestesia ditemukan sebanyak 16 buah (13,6\%). Data tersebut menunjukkan kemunculan metafora bercitra antropomorfik dengan bentuk predikatif di dalamnya lebih banyak dibandingkan dengan pilihan citra lainnya, karena metafora dengan kemiripan pengalaman anggota tubuh (antropomorfik) dan bentuk predikatif merupakan metafora yang lebih sering digunakan oleh penulis dari artikel rubrik opini.
\end{abstract}

Kata kunci: Metafora, pilihan citra dan bentuk, rubrik opini harian Kompas.

\section{PENDAHULUAN}

Bahasa memiliki peran yang fundamental dalam kehidupan manusia sebagai penggerak kehidupan manusia. Peran bahasa yang fundamental tersebut menjadikan manusia memiliki ketergantungan pula pada bahasa. Manusia dapat mengenali, mengungkap, mengetahui, dan memahami segala sesuatunya melalui bahasa. Bahasa dapat dikatakan sebagai kunci dari segala jalan. Dengan bahasa, manusia dapat masuk ke berbagai bidang kehidupan.

Manusia sebagai makhluk sosial tidak pernah berhenti dari kegiatan berpikir, berinteraksi, berkomunikasi, dan berekspresi. Aktivias berpikir menghasilkan ide, opini, sikap, tindakan, pengalaman, dan sebagainya yang dapat berupa pernyataan, pertanyaan, perintah, permintaan, ajakan, imbauan, atau seruan (Sugono, 2014: 12). Aktivitas berpikir tersebut diungkapkan manusia melalui bahasa. Begitupun dengan berinteraksi, berkomunikasi, berekspresi yang diungkapkan manusia melalui bahasa. Dalam kaitannya manusia dengan aktivitas berekspresi, bahasa dapat diekspresikan atau diungkapkan melalui banyak hal. Salah satunya, manusia dapat mengekspresikan muatan emosionalnya melalui tulisan Dalam sebuah tulisan, hal-hal yang berasal dari muatan emosional manusia 
dapat diungkapkan dengan makna sebagai representasi maksud emosional manusia yang tidak terbatas.

Penggunaan bahasa dalam fenomena kebahasaan sehari-hari banyak mengandung makna sebagai representasi maksud manusia yang tidak terbatas. Makna yang hadir tidak hanya berhenti sampai makna sebenarnya saja, hadir pula makna kiasan, dan sering pula muncul makna sesuai dengan konteks kebahasaan (kontekstual). Fenomena kebahasaan bisa terjadi baik secara lisan maupun tulisan. Seperti pada fenomena bahasa berikut ini:

Ruang politik kian dipenuhi warna- warni "lipstik", "bedak", dan "parfum" untukmembangkitkan "gairah" dan "selera politik". Siapa sangka, "penampilan" kini jadi "jantung" kehidupan politik, dan "kosmetika" adalah cara utama memanipulasi penampilan agar tampak menarik“ (Piliang, 2013).

Dari contoh kutipan di atas terdapat bentuk - bentuk bahasa seperti lipstik, bedak, parfum,gairah, selera politik, penampilan, jantung, kehidupan politik, kosmetika. Kata lipstik memiliki makna 'pewarna bibir', namun dalam teks tersebut kata lipstik dihadirkan oleh penulis dengan makna 'pencitraan'. Lalu kata bedak memiliki makna 'serbuk halus untuk mempercantik muka', namun dalam teks tersebut bedak dihadirkan oleh penulis menjadi bermakna 'tampilan luar'. Begitupun dengan kata parfum yang memiliki makna 'bau wangi-wangian', namun dalam teks tersebut parfum dihadirkan oleh penulis menjadi bermakna 'Aroma politik'. Secara garis besar, makna dari bentuk - bentuk bahasa yang penulis hadirkan tersebut dapat dikaji dalam studi semantik. Bentuk - bentuk bahasa lainnya ditemukan pada fenomena bahasa seperti berikut ini.

Tak satu Negara pun yang bisa mengukur korupsi aktual yang terjadi. Dari semua studi yang ada, kita tetap bisa membuat kesimpulan bahwa ongkos korupsi itu sangat mahal walaupun bisa dikatakan bahwa estimasi moneter atau nilai persentase korupsi itu tak mencerminkan angka sebenarnya dan, karenanya, tak pernah menjadi jantung dari diskursus mengenai korupsi (Lubis, 2014).

Dari contoh kutipan di atas terdapat bentuk bahasa seperti korupsi aktual, ongkos korupsi, dan jantung. Pada bentuk bahasa korupsi aktual, kata korupsi memiliki makna 'penyelewengan atau penyalahgunaan uang Negara untuk kepentingan pribadi' penulis menghadirkan kata tersebut dengan makna sebenarnya. Namun, kata aktual memiliki makna 'betul - betul ada (terjadi)' yang penulis hadirkan dengan konteks maksud untuk mengungkapkan korupsi yang benar - benar terjadi. Pada bentuk bahasa ongkos korupsi, kata ongkos memiliki makna 'biaya' penulis menghadirkan kata tersebut dengan konteks maksud untuk mengungkapkan adanya biaya yang digunakan dalam kegiatan korupsi. Pada bentuk bahasa jantung, kata jantung memiliki makna 'bagian tubuh yang menjadi pusat peredaran darah'. Penulis menghadirkan kata tersebut dengan konteks maksud untuk mengungkapkan adanya pusat peredaran korupsi. Secara garis besar, bentuk - bentuk bahasa tersebut dapat pula menjadi bagian dari kajian studi semantik.

Dari kedua fenomena tersebut ditemukan adanya bentuk-bentuk bahasa seperti ungkapan. Karena bentuk - bentuk bahasa tersebut dipakai oleh penulis untuk merepresentasikan gagasan dan emosinya dalam tulisan. Dalam studi semantik, gaya pengungkapan bahasa tersebut dapat disebut sebagai metafora. Bahasa manusia sebenarnya penuh dengan ungkapan metafora. Metafora hadir untuk memenuhi muatan emosional manusia yang tidak terbatas baik dalam berujar ataupun tulisan. Kemunculan metafora bukan sesuatu yang asing karena dalam berpikir dan berkomunikasi, karena sebenarnya 
manusia sering mengungkapkannya dengan metafora. Bentuk - bentuk seperti bahu jalan, cepat kilat, raja siang merupakan beberapa contoh bentuk metafora yang tidak asing diketahui. Bentuk bahu jalan, cepat kilat, raja siang merupakan metafora karena ada sesuatu perbandingan dan persamaan di dalamnya. Metafora merupakan ungkapan kebahasaaan yang maknanya tidak dapat dijangkau secara langsung dari lambang yang dipakai karena makna yang dimaksud terdapat pada prediksi ungkapan kebahasaan itu (Wahab, 1990: 142).

Gaya pengungkapan bahasa seperti metafora memang hanya terlihat sebagai makna kiasan untuk memperindah bahasa sehari - hari. Meskipun begitu metafora ternyata memiliki andil dalam penciptaan kata baru. Metafora memiliki posisi untuk menggambarkan sesuatu fenomena yang baru. Sehingga masyarajat mengerti dalam memahami sebuah fenomena yang benar - benar baru. Dengan demikian fenomena metafora dalam bahasa adalah salah satu cara berpikir manusia. Penggunaan metafora seperti pada fenomena bahasa di atas secara khusus ditemukan pada artikel rubrik opini salah satu harian media massa. Artikel yang berada pada rubrik opini merupakan tulisan lepas mengenai pelbagai soal aktual yang bersifat opini pribadi penulisnya ${ }^{5}$. Penggagas dari artikel pada rubrik opini tersebut berasal dari kiriman penulis luar yang sebagian besar berasal dari kalangan akademisi seperti dosen, budayawan, atau kritikus. Artikel jurnalistik dalam rubrik opini tersebut berasal dari opini penulisnya, namun tetap bertolak pada sejumlah referensi yang penulisnya kumpulkan sendiri ataupun wawancara.

Dalam sebuah tulisan opini terkandung unsur subjektifitas yang kuat dari sisi penulisnya. Oleh karena itulah artikel di rubrik opini banyak memunculkan metafora. Penggunaan metafora oleh penulis artikel di rubrik opini mengarah untuk menyampaikan pendapat, gagasan, kritik serta emosinya terhadap sesuatu fenomena yang sedang terjadi. Rubrik opini sebagai gaya ungkap dimungkinkan banyaknya penggunaan metafora. Penggunaan metafora di media massa, khususnya pada rubrik opini menjadi menarik untuk dicari tahu lebih lanjut. Dalam opini, penulis mengutarakan gagasan, pendapat, kritik yang ditujukan untuk meyakinkan dan mengarahkan pembaca perihal suatu topik tertentu. Karena setiap tulisan pasti memiliki gaya kepenulisannya sendiri termasuk gaya pengungkapan bahasa metafora yang jenisnya berbeda- beda di dalam tulisan tersebut.

Berdasarkan penjabaran tersebut, dapat dirumuskan masalah penelitian yakni, Bagaimanakah penggunaan metafora dalam rubrik opini Harian Kompas ditinjau dari segi jenis metafora yang muncul. Tinjauan pustaka dalam penelitian ini dimulai dari kajian Semantik, sebagai payung dari metafora. Kemudian, teori perubahan makna, teori metafora mencakup jenis metafora berdasarkan pilihan citra dan bentuk, serta rubrik opini Harian Kompas.

Dalam bidang linguistik, semantik merupakan studi yang mempelajari hubungan antara tanda - tanda linguistik dengan hal - hal yang ditandainya. Chaer menyebutkan bahwa dapat pula semantik diartikan sebagai bidang studi dalam linguistik yang mempelajari makna atau arti dalam bahasa(Chaer, 2007: 31). Sejalan dengan hal tersebut, J.D Parera menyebut pula bahwa semantik adalah satu studi dan analisis tentang makna makna linguistik ${ }^{7}$. Salah satu fenomena telaah dari semantik ialah Perubahan makna. Perubahan makna merupakan gejala pergantian rujukan dari simbol bunyi yang sama (Parera, 2004: 42). Lebih lanjut Parera mengemukakan perubahan makna berarti adanya penggantian rujukan.

Perubahan makna menurut Gorys Keraf terdiri atas beberapa jenis yakni (1) perluasan arti, (2) penyempitan arti, (3) ameliorasi, (4) peyorasi, (5) metafora dan (6) metonimi. Berikut penjabaran mengenai masing - masing jenis perubahan makna menurut Gorys Keraf. Perluasan Arti. Metafora. Merupakan perubahan makna karena persamaan 
sifat antara duaobjek. Dapat dikatakan metafora merupakan perubahan makna yang dilihat dari sudut persepsi kemiripan fungsional antara dua obyek. Contohnya pada kata matahari, putri malam (untuk bulan), pulau (empu laut), beberapa contoh metafora tersebut dibentuk berdasarkan metafora. Metonimi. Sebagai suatu proses perubahan makna yang terjadi karena hubungan erat antara kata-kata yang terlibat dalam suatu lingkungan makna yang sama, dan dapat diklasifikasi menurut tempat atau waktu, menurut hubungan isi dan kulit, menurut hubungan sebab dan akibat. Contohnya pada kata kota tadinya berarti susunan batu yang dibuat mengelilingi sebuah tempat pemukiman sebagai pertahanan terhadap serangan dari luar. Sekarang tempat tersebut tetap disebut kota, walaupun sudah tidak ada susunan batunya lagi. Menurut Gorys Keraf, metafora adalah perubahan makna karena persamaan sifat antara dua obyek. Ia merupakan pengalihan semantik berdasarkan kemiripan persepsi makna (Keraf, 1985: 95-99).

Wahab dalam PELLBA 3 mengemukakan mengenai metafora yakni metafora merupakan ungkapan kebahasaaan yang maknanya tidak dapat dijangkau secara langsung dari lambang yang dipakai karena makna yang dimaksud terdapat pada prediksi ungkapan kebahasaan itu (Wahab, 1990: 142). Serupa dengan Wahab, Kridalaksana dalam kamus linguistik menyebutkan pula bahwa metafora merupakan suatu ungkapan. Metafora merupakan pemakaian kata atau ungkapan lain untuk objek atau konsep lain berdasarkan kias atau persamaan (Kridalaksana, 2008). Penggolongan metafora dalam semantik agaknya memiliki banyak sudut pandang perbedaan dari para ahli. Gorys Keraf menggolongkan metafora dalam buku diksi dan gaya bahasa sebagai bagian dari perubahan makna. Sejalan dengan pandangan tersebut, J.D.Parera menggolongkan metafora sebagai fenomena terpenting dalam hakikat perubahan makna (Parera, 2004: 119).

Menurut J.D.Parera, jenis metafora berdasarkan pilihan citra yang dipakai oleh pemakai bahasa dan para penulis di berbagai bahasa dapat dibedakan atas empat kelompok, yakni (1) metafora bercitra antropomorfik, (2) metafora bercitra hewan, (3) metafora bercitra abstrak ke konkret, (4) metafora bercitra sinestesia atau pertukaran tanggapan atau persepsi indra (Parera, 119). Selain jenis metafora berdasarkan pilihan citra tersebut, terdapat pula jenis metafora berdasarkan bentuk. Jenis metafora berdasarkan bentuk ini dikemukakan oleh Abdul Wahab bahwa jenis metafora berdasarkan bentuk dibedakan atas tiga kelompok yakni (1) Metafora nominatif, mencakup metafora nominatif subjektif dan nominatif objektif (2) Metafora predikatif, (3) Metafora kalimat (Wahab, 1990: 77).

Teks yang menjadi objek dalam penelitian ini adalah rubrik opini Harian Kompas. Teks tersebut berupa artikel opini yang terdapat dalam rubrik opini Harian Kompas. Wahyu Wibowo dalam Berani Menulis Artikel menyebut artikel opini yang berada pada rubrik opini tersebut sebagai artikel jurnalistik. Artikel jurnalistik adalah tulisan lepas mengenai pelbagai soal aktual yang bersifat opini pribadi penulisnya. Meskipun bersifat opini pribadi penulisnya, artikel dalam rubrik opini tersebut tidak begitu saja mentah berdasarkan opini. Biasanya penulis artikel berangkat dari sejumlah referensi, entah itu kepustakaan atau hasil wawancara (Wahab, 1990: 28).

Berikut kerangka berpikir dari tinjauan pustaka atau landasarn teori yang telah dipaparkan ; Salah satu telaah dari studi semantik yang merupakan studi tentang makna adalah perubahan makna. Perubahan makna merupakan gejala pergantian rujukan dari simbol bunyi yang sama. Perubahan makna terdiri dari beberapa jenis yang salah satu jenisnya yakni Metafora. Metafora adalah gaya pengungkapan bahasa mengenai perbandingan dan kemiripan suatu konsep dengan konsep lain untuk mengalihkan persepsi. Jenis metafora ini meliputi dua bagian yakni ; berdasarkan pilihan citra yang meliputi 
metafora bercitra antropomorfik, abstrak ke konkret, hewan, sinestesia. Jenis metafora berdasarkan bentuk meliputi metafora nominatif subjektif dan objektif, metafora predikatif, metafora kalimat. Kedua jenis tersebut dapat dijadilan acuan untuk menganalisis sebuah metafora. Penggunaan metafora dapat ditemukan di berbagai teks khususnya pada rubrik opini. Rubrik opini adalah ruangan dalam media massa yang khusus disediakan untuk tulisan lepas mengenai berbagai soal aktual yang bersifat opini pribadi penulisnya. Teks yang menjadi objek dalam penelitian ini adalah rubrik opini harian kompas. Teks tersebut berupa artikel opini yang terdapat dalam rubrik opini harian kompas. Analisis dari penelitian ini lebih ditekankan pada jenis metafora berdasarkan pilihan citra dan bentuk.

\section{METODE PENELITIAN}

Tujuan penelitian ini adalah untuk mengetahui bagaimana penggunaan metafora dalam rubrik opini Harian Kompas ditinjau dari jenis berdasarkan pilihan citra dan jenis berdasarkan bentuk metafora yang muncul dalam rubrik opini Harian Kompas tersebut. Penelitian ini tergolong penelitian kajian pustaka. Maka, penelitian ini tidak dibatasi tempat. Penelitian ini dilakukan pada Maret sampai dengan Juni 2014. Berdasarkan jangkauan waktu, penelitian ini tergolong penelitian sinkronis(Djajasudarma, 1993: 7).

Objek atau korpus pada penelitian ini adalah rubrik opini harian kompas. Dalam satu bulan Harian Kompas terdapat 90 rubrik opini. Ke-90 rubrik opini tersebut direduksi 1/3, menjadi 30 rubrik opini. Lalu, pengambilan data metafora dilakukan secara purposive sampling yakni, menemukan metafora dengan mengambil secara acak rubrik opini yang terbit dari bulan Januari sampai Maret. Penelitian ini difokuskan pada penggunaan metafora pada rubrik opini harian kompas ditinjau berdasarkan pilihan citra dan bentuk metafora yang muncul. Metode penelitian yang akan digunakan dalam penelitian ini adalah metode kualitatif deskriptif dengan teknik analisis isi. Metode penelitian kualitatif merupakan prosedur yang menghasilkan data deskriptif berupa data tertulis atau lisan di masyarakat bahasa. Dalam hal ini berarti dilakukan analisis berupa jenis metafora berdasarkan pilihan citra dan bentuk yang muncul dalam rubrik opini harian kompas. Metode deskriptif merupakan gambaran ciri - ciri data secara akurat sesuai dengan sifat alamiah itu sendiri (Djajasudarma, 1993: 10-15).

Instrumen penelitian yang digunakan dalam penelitian ini adalah peneliti sendiri dibantu dengan tabel analisis kerja yang dirumuskan dari teori. Memilih objek penelitian yakni rubrik opini Harian Kompas..adapun teknik pengumpulan data meliputi, membaca secara intensif rubrik opini Harian Kompas edisi Januari - Maret 2014. Membaca secara intensif yang dimaksud adalah membaca secara terus menerus rubrik opini Harian Kompas edisi Januari sampai dengan edisi Maret 2014, Mereduksi rubrik yang akan dijadikan sebagai objek penelitian. Mereduksi rubrik yang dimaksud adalah mengurangi atau menyeleksi data (rubrik opini Haria Kompas), Menginventarisasi 30 rubrik opini (hasil reduksi) Harian Kompas edisi Januari - Maret 2014, Membaca secara cermat rubrik opini yang telah direduksi tersebut, untuk menemukan metafora. Membaca secara cermat yang dimaksud adalah membaca rubrik opini Harian Kompas yang telah direduksi secara teliti untuk menemukan metafora, menandai paragraf-paragraf yang mengandung metafora, memisahkan kalimat yang mengandung metafora dari paragraf yang sudah diberi tanda.

Analisis data pada penelitian ini dilakukan secara induktif yakni data dikaji melalu proses yang berlangsung dari fakta (data) ke teori (Djajasudarma, 1993: 13). Analisis data ini dilakukan dengan beberapa langkah - langkah sebagai berikut ; memasukkan kalimat bermetafora ke dalam tabel analisis data, mengelompokkan jenis metafora berdasarkan pilihan citra dan bentuk, menganalisis data sesuai tabel analisis beserta deskripsi analisisnya berdasarkan hasil analisis, menghitung frekuensi data, membuat rekapitulasi 
Arkhais, Vol. 06 No. 1 Januari-Juni 2015

data, memberi interpretasi hasil analisis data, melakukan pembahasan data metafora yang ditemukan.

\section{HASIL DAN PEMBAHASAN}

Berdasarkan penelitian yang telah dilakukan, dapat ditemukan bahwa dalam rubrik opini harian Kompas terdapat metafora sebanyak 121 metafora dari 110 kalimat metaforis. Dari seluruh data tersebut, terdapat 117 metafora yang mengandung citra antropomorfik, citra hewan, citra abstrak ke konkret, citra sinestesia dan menempati bentuk yang meliputi nominatif subjektif, nominatif objektif, predikatif, kalimat. Sisa yang tidak menempati citra dan bentuk,terdapat 4 metafora yang menempati bentuk saja, atau citra saja.

Berdasarkan tabel di atas, dapat dilihat bahwa terdapat 117 metafora yang menempati pilihan citra dan bentuk. Metafora yang menempati pilihan citra terkandung di dalam 117 metafora tersebut terdiri dari metafora bercitra antropomorfik sebanyak 39 buah $(33,4 \%)$ terdiri atas 4 nominatif subjektif, 7 nominatif objektif, 27 predikatif, dan 1 kalimat. Kemudian metafora bercitra hewan ditemukan sebanyak 25 buah $(21,4 \%)$ terdiri atas 3 nominatif subjektif, 9 nominatif objektif, 12 predikatif, dan 1 kalimat. Selanjutnya, metafora bercitra abstrak ke konkret ditemukan sebanyak 37 buah $(31,6 \%)$ terdiri atas 4 nominatif subjektif, 17 nominatif objektif, 16 predikat. Metafora bercitra sinestesia ditemukan sebanyak 16 buah $(13,6 \%)$ terdiri atas 2 nominatif subjektif, 10 nominatif objektif, 3 predikatif, dan 1 kalimat. Selain itu, terdapat pula bentuk metafora yang sesuai pilihan citra yakni, metafora berbentuk nominatif subjektif ditemukan sebanyak 13 buah $(11,2 \%)$, metafora berbentuk nominatif objektif ditemukan sebanyak 43 buah $(36,7 \%)$, metafora berbentuk predikatif ditemukan sebanyak 58 buah (49,6\%), dan metafora berbentuk kalimat ditemukan sebanyak 3 buah (2,5\%).

Dari hasil rekapitulasi tabel analisis dapat diketahui bahwa jumlah metafora berdasarkan pilihan citra terbanyak terdapat pada metafora bercitra antropomorfik berjumlah 39 buah yang di dalamnya terdapat 27 metafora bercitra antropomorfik berbentuk predikatif. Metafora berdasarkan bentuk secara keseluruhan dapat diketahui jumlah terbanyak terdapat pada metafora bentuk predikatif dengan jumlah 58 buah. Sedangkan metafora dengan kemunculan sedikit terdapat pada metafora bercitra sinestesia dan metafora berbentuk kalimat.

Tingginya jumlah kemunculan metafora bercitra antropomorfik sebenarnya disebabkan metafora dengan kemiripan pengalaman anggota tubuh (antropomorfik) merupakan metafora yang lebih sering digunakan oleh penulis. Penggunaan bercitra antropomorfik terbanyak berkaitan dengan pembaca (manusia) untuk itu, penulis merepresentasikan maksudnya melalui kesamaan sifat atau pengalaman anggota tubuh, agar mudah menyampaikan maksud sebenarnya kepada pembaca. Penggunaan bentuk predikatif terbanyak oleh penulis opini karena, bentuk predikatif merupakan pernyataan. Penulis opini ingin mengatakan sesuatu berkaitan dengan pemikirannya dalam artikel melalui bentuk predikatif.

\section{KESIMPULAN}

Penelitian ini masih banyak terdapat keterbatasan, sebagai berikut: (1) Keterbatasan peneliti pada teori yang kurang, sehingga terkadang menjadi hambatan dalam proses analisis data. (2) Keterbatasan peneliti pada instrumen penelitian yang digunakan. Yaitu peneliti sendiri dengan dibantu tabel analisis kerja yang memungkinkan terjadinya kesalahan dalam proses penentuan data dan analisis data. (3) Keterbatasan peneliti pada ranah penelitian yang difokuskan oleh peneliti. Penelitian ini hanya difokuskan untuk 
Arkhais, Vol. 06 No. 1 Januari-Juni 2015

menemukan metafora berdasarkan pilihan citra dan bentuk, sehingga tidak menutup kemungkinan ada penemuan metafora lainnya yang tidak masuk ke dalam ranah pilihan citra dan bentuk seperti munculnya kata baru melalui metafora.

Metafora sebenarnya begitu banyak digunakan oleh orang saat berbahasa, baik melalui tulisan ataupun lisan. Terutama tulisan - tulisan yang sifatnya informatif dan provokatif seperti pada rubrik opini harian Kompas. Metafora yang muncul melalui tulisan tersebut menjadi sangat menarik untuk dikaji dan diteliti. Kemunculan metafora juga tidak terbatas pada satu bidang saja, oleh karena itu, bagi peneliti lain yang ingin meneliti metafora bisa menjadikan tulisan di media baik media cetak, televisi , atau media online (dalam jaringan) sebagai salah satu alternatif bahan penelitian. Selain melalui tulisan, peneliti lain dapat pula menggali metafora melalui pertuturan (lisan) melalui media lainnya. Selain itu, adanya penggunaan metafora juga tidak menutup kemungkinan munculnya kata baru dan makna baru. peneliti lain bisa menjadikan kedua hal tersebut sebagai bahan penelitian selanjutnya mengenai ranah metafora.

\section{DAFTAR RUJUKAN}

Chaer, Abdul.2007. Pengantar Semantik Bahasa Indonesia. Jakarta: Rineka Cipta .2007. Linguistik umum. Jakarta: Rineka Cipta

Djajasudarma,T. Fatimah. 1993. Metode linguistik-ancangan metode penelitian dan kajian. Bandung : Eresco.

Keraf, Gorys.1985. Diksi dan Gaya Bahasa. Jakarta: Gramedia Pustaka Utama.

Kridalaksana. 2008. Kamus Linguistik.Jakarta: Gramedia Pustaka Utama.

Lubis, Todung Mulya. Korupsi Bukan Cuma Soal Uang, Kompas, 8 Januari 2014

Parera, J.D. 2004. Teori Semantik. Jakarta: Erlangga

Piliang, Yasraf Amir. Atas Nama Rakyat.Kompas 9 Desember 2013

Sugono, Dendy. 2014. Peran dan Kekuatan Bahasa Indonesia dalam Industri KreatifKebahasaan. Jakarta: Badan Pengembangan dan Pembinaan Bahasa.

Wahab, Abdul. 1990. Metafora sebagai Alat Pelacak Sistem Ekologi dalam PELLBA 3: Pertemuan Linguistik Lembaga Bahasa Atma Jaya Ketiga. Jakarta: Kanisius. 
Arkhais, Vol. 06 No. 1 Januari-Juni 2015 